Electronic scientific and practical journal INTELLECTUALIZATION OF LOGISTICS AND SUPPLY CHAIN MANAGEMENT

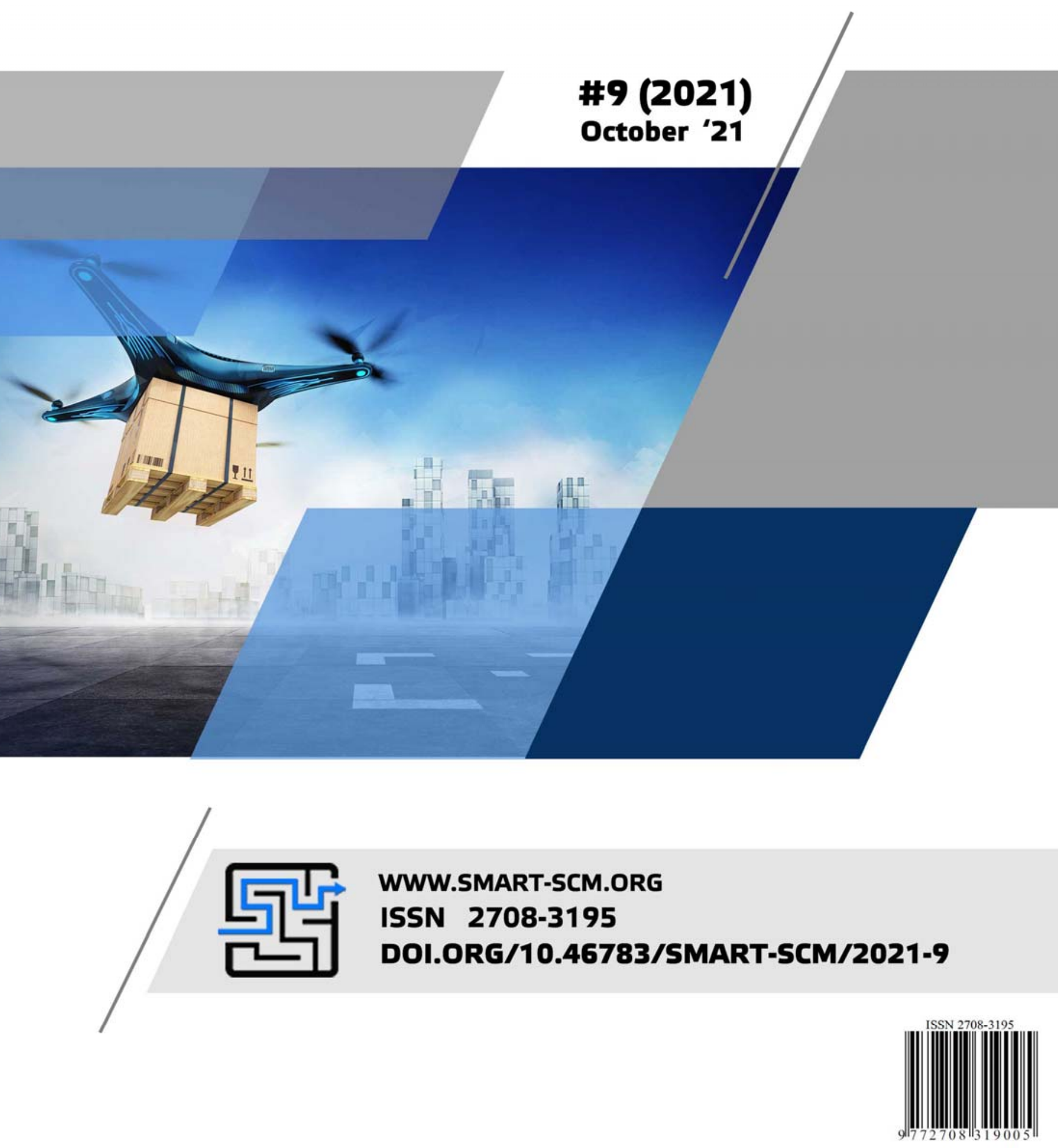




\section{Electronic scientific and practical collection
INTELLECTUALIZATION OF LOGISTICS
AND SUPPLY CHAIN MANAGEMENT}

Electronic scientific and practical publication in economic sciences

ISSN 2708-3195

DOl: https://doi.org/10.46783/smart-scm/2021-9

Released 6 times a year

№ 9 (2021)

October 2021

Kyiv - 2021 
Founder: Viold Limited Liability Company

Editor in Chief:

Deputy editors-in-chief:

Technical editor:

Executive Secretary:
Hryhorak M. Yu. - Doctor of Economics, Ass. Professor.

Koulyk V. A. - PhD (Economics), Professor.

Marchuk V. Ye. - Doctor of Tech. Sci., Ass. Professor.

Harmash O. M. - PhD (Economics), Ass. Professor.

Davidenko V. V. - PhD (Economics), Ass. Professor.

\section{Members of the Editorial Board:}

SWIEKATOWSKI Ryszard - Doctor of Economics, Professor (Poland);

POSTAN M. Ya. - Doctor of Economics, Professor;

TRUSHKINA N. V. - PhD (Economics), Corresponding Member of the Academy;

KOLOSOK V. M. - Doctor of Economics, Professor;

ILCHENKO N. B. - Doctor of Economics, Ass. Professor;

SOLOMON D. I. - Doctor of Economics, Professor (Moldova);

ALKEMA V. H. - Doctor of Economics, Professor;

Henryk DŹWIGOŁ - PhD (Economics), Professor (Poland);

SUMETS O. M. - Doctor of Economics, Ass. Professor;

STRELCOVÁ Stanislava - PhD (Economics), Ass. Professor, (Slovakia);

RISTVEJ Jozef (Mr.) PhD (Economics), Professor, (Slovakia);

ZAMIAR Zenon - Doctor of Economics, Professor, (Poland);

SMERICHEVSKA S. V. - Doctor of Economics, Professor;

GRITSENKO S. I. - Doctor of Economics, Professor;

KARPENKO O. O. - Doctor of Economics, Professor;

PATKOVSKYI S. A. - Business practitioner.

The electronic scientific and practical journal is registered in international scientometric data bases, repositories and search engines. The main characteristic of the edition is the index of scientometric data bases, which reflects the importance and effectiveness of scientific publications using indicators such as quotation index, h-index and factor impact (the number of quotations within two years after publishing).

In 2020, the International Center for Periodicals (ISSN International Center, Paris) included the Electronic Scientific and Practical Edition "Intellectualization of Supply Chain Management" in the international register of periodicals and provided it with a numerical code of international identification: ISSN 2708-3195 (Online).

Recommended for dissemination on the Internet by the Academic Council of the Department of Logistics NAU (No. 7 of February 26, 2020). Released 6 times a year. Editions references are required. The view of the editorial board does not always coincide with that of the authors.

t.me/smart_scm facebook.com/Smart.SCM.org twitter.com/ScmSmart

DOI: https://doi.org/10.46783/smart-scm/2021-9 e-mail: support@smart-scm.org тел.: (063) 593-30-41

https://smart-scm.org 


\section{Contents}

INTRODUCTION

BUGAYKO D.O. PhD in Economics, Associate Professor, Vice - Director of International Cooperation and Education Institute, Instructor of ICAO Institute, Associate Professor of Logistics Dept. National Aviation University (Ukraine), IERKOVSKA Y.M. Lawyer (Ukraine) INSTITUTIONAL MEASURES OF AIR TRANSPORT SAFETY STRATEGIC MANAGEMENT AT THE LEVEL OF STATE REGULATION

POZNIAK O.V. PhD (Economics), Associate Professor, Associate Professor of Logistics Department, National Aviation University (Ukraine), KHMYLIEVSKA V.V. $\mathrm{PhD}$ (Economics and Organization Management) Associate Professor (Organizational Management and Logistics department), F. Hoffmann La-Roche (Switzerland), ISHIMWE M. J. Master ' degree student of Logistics Department, National Aviation University (Ukraine) LOSSES IN PHARMACEUTICAL SUPPLY CHAINS: CHALLENGES IN EFFICIENT VACCINE DISTRIBUTION AND UTILIZATION

SAVCHENKO L.V. PhD of Technical Sciences, Associate Professor, Associate Professor of Logistics Department of National Aviation University (Ukraine), SEMERIAHINA M.M. Senior Lecturer of Logistics Department, National Aviation University (Ukraine), SHEVCHENKO I.V. PhD of Economic Sciences, Associate Professor of higher mathematics department of the National Aviation University (Ukraine) MODELING DAILY DYNAMICS OF SPEED AND FUEL CONSUMPTION FOR URBANDELIVERY MEANS

KOSTIUCHENKO L.V. PhD in Economics, Associate Professor, Associate Professor of logistics Department of National Aviation University (Ukraine), MARCHUK V.Ye Doctor of Engineering, Associate Professor, Professor of Logistics Department National Aviation University (Ukraine), HARMASH O.M., PhD of Economics, Associate Professor, Associate Professor of Logistics Department of National Aviation University (Ukraine)

DEVELOPMENT OF RECYCLING INFRASTRUCTURE IN UKRAINE

SUMETS O.M. Doctor of Economics, Professor, Professor of The Integration Academy of Personnel Management (Ukraine)

THE EVENTUAL MODEL OF THE ALGORITHM FOR DESIGNING THE LOGISTICS SYSTEM OF A PRODUCTION ENTERPRISE

\section{EVENTS AND SCIENTIFIC CONFERENCES}

D.I. Solomon, P.I. Stetsiuk, M.Yu. Hryhorak - THE SCIENTIFIC CONFERENCE'S RESULTS: LOGISTIC VIEW "Mathematical modeling, optimization and information technology" 
UDC 656.7.072 (045)

DOI: https://doi.org/10.46783/smart-scm/2021-9-1

JEL Classification: M12, M21, Q20.

Received: 08 September 2021

Bugayko D.o. PhD in Economics, Associate Professor, Vice - Director of International Cooperation and Education Institute, Instructor of ICAO Institute, Associate Professor of Logistics Dept. National Aviation University (Ukraine)

ORCID - 0000-0001-9901-4792

Researcher ID -

Scopus author id: 57216582348

lerkovska Y.M. Lawyer (Ukraine)

ORCID -

Researcher ID -

Scopus author id: -

\title{
INSTITUTIONAL MEASURES OF AIR TRANSPORT SAFETY STRATEGIC MANAGEMENT AT THE LEVEL OF STATE REGULATION
}

\begin{abstract}
Dmytro Bugayko, Yuliya lerkovska "Institutional Measures of Air Transport Safety Strategic Management at the Level of State Regulation". World leaders gathered at the United Nations (UN) and adopted the 2030 Agenda for Sustainable Development. It is a plan of action aimed at achieving global sustainable development in economic, social and environmental areas, which ensures that no UN member state is left behind. The 17 sustainable development goals on the 2030 Agenda can be used as benchmarks for the coordinated development of UN member states. Aviation safety is an important component of the concept of general national security, the system of personal security, ecological and public safety and transport safety from external and internal threats. Maintaining an acceptable level of national aviation safety is a priority for the industry. The aviation transport is a part of the transport complex of Ukraine, which is an important component in the structure of the national economy and a link between all components of economic security to ensure the basic conditions of life and development of the state and society.

The assessment of economic, technological, safety, social and ecological hazards is an integral part of all the logical blocks of the structural and functional scheme of strategic management of aviation safety in terms of sustainable development of the national economy. According to the concept of national aviation risk management developed by the authors, risk can be assessed as a mutual combination of hazarad, vulnerability and consequences. The application of this concept in relation to the air transport of Ukraine allowed to identify the main hazards, vulnerabilities, consequences and risks. The next step in the implementation of the concept is to develop institutional measures to neutralize threats in the field of aviation safety, which is actually a set of risk reduction measures for further sustainable development of the national economy. This article summarizes the hazards, vulnerabilities, consequences, risks, and institutional arrangements for strategic aviation safety management. Among the priority measures are: harmonization of national regulation of air transport with the requirements of global and regional levels, development of mechanisms for commercial protection of domestic air transport enterprises in the COVID-19 pandemic, implementation of strategic scenarios for sustainable development of air transport in Ukraine until 2030. The implementation of the proposed institutional measures will ensure an appropriate level of safety, efficiency and regularity of the national air transport of Ukraine.
\end{abstract}

Keywords: air transport, state regulation, aviation safety, hazards, risks, institutional measures. 
Дмитро Бугайко, Юлія Єрковська "Інституційні заходи стратегічного управління безпекою авіаційного транспорту на рівні державного регулювання". Світові лідери зібрались в Організачії Об'єднаних Націй (ООН) та прийняли Порядок денний сталого розвитку до 2030 року. Це план дій, спрямований на досягнення глобального сталого розвитку в економічній, соціальній та екологічній сферах, який гарантує, що жодна держава-член ООН не залишиться позаду. 17 чілей сталого розвитку, викладениху Повістиі дня на 2030 рік, можуть бути використані як орієнтири для скоординованого розвитку держав-членів ООН. Безпека авіації $\epsilon$ важливою складовою концепиії загальної національної безпеки, системи особистої безпеки, екологічної та громадської безпеки та безпеки транспорту від зовнішніх та внутрішніх загроз. Підтримання прийнятного рівня національної безпеки авіації є пріоритетом для галузі. Авіаційно-транспортна галузь є системою відкритого типу, на яку впливає широкий спектр технічних, природних, людських та економічних небезпек. Кожна небезпека спричиняє створення низки ризиків.

Авіаційний транспорт є частиною транспортного комплексу України та важливою складовою в структурі економіки країни та сполучною ланкою між усіма складовими економічної безпеки для забезпечення основних умов життя та розвитку держави та суспільства. Оцінка економічних, технологічних, соціальних та екологічних загроз $\epsilon$ невід'ємною частиною всіх логічних блоків структурно-функціональної схеми стратегічного управління авіачійною безпекою з точки зору сталого розвитку національної економіки. Згідно з розробленою авторами кончепчією національного управління ризиками ризик можна оцінити як взаємне поєднання загрози, вразливості та наслідків. Застосування цієї концепції по відношенню до авіаційного транспорту України дозволило виявити основні загрози, вразливості наслідки та ризики. Наступний крок реалізації концепції полягає в розробленні інституційних заходів нейтралізації загроз у сфері безпеки авіації, що фактично $\epsilon$ комплексом заходів зменшення ризиків з метою подальшого сталого розвитку начіональної економіки. Зведену інформачію про загрози, вразливості, наслідки, ризики та інституційні заходи щодо стратегічного управління безпекою авіачійного транспорту наведено у чій статті. Серед першочергових заходів можливо виділити: гармонізацію начіонального регулювання авіаційного транспорту з вимогами світового та регіонального рівнів, розроблення механізмів комериійного захисту вітчизняних підприємств авіачійного транспорту в умовах пандемії COVID-19, імплементацію стратегічних сценаріїв сталого розвитку авіаційного транспорту України в безпековому вимірі на період до 2030 року. Реалізація запропонованих інститучійних заходів дозволить забезпечити відповідний рівень безпеки, ефективності та регулярності національного авіаційного транспорту України.

Ключові слова: авіаційний транспорт, державне регулювання, безпека авіації, загрози, ризики, інституційні заходи.




общества. Оченка экономических, технологических, сочиальных и экологических угроз является неотьемлемой частью всех логических блоков структурно-функциональной схемы стратегического управления авиачионной безопасностью с точки зрения устойчивого развития национальной экономики. Согласно разработанной авторами концепиии национального управления рисками риск можно оценить как взаимное сочетание угрозы, уязвимости и последствий. Применение этой концепции по отношению к авиационному транспорту Украины позволило выявить основные угрозы, уязвимости, последствия и риски. Следующий шаг реализации концепиии заключается в разработке институчиональных мер нейтрализачии угроз в сфере безопасности авиачии, что фактически является комплексом мер по уменьшению рисков с челью дальнейшего устойчивого развития начиональной экономики. Сводная информация об угрозах, уязвимости, последствиях, рисках и институциональных мерах по стратегическому управлению безопасностью авиачионного транспорта приведена в этой статье. Среди первоочередных мер можно выделить: гармонизацию начионального регулирования авиачионного транспорта с требованиями мирового и регионального уровней, разработку механизмов коммерческой защиты отечественных предприятий авиачионного транспорта в условиях пандемии COVID-19, имплементачию стратегических сценариев устойчивого развития авиачионного транспорта Украины в измерении безопасности на период до 2030 года. Реализачия предложенных институчиональных мер позволит обеспечить соответствующий уровень безопасности, эффективности и регулярности начионального авиачионного транспорта Украины.

Ключевые слова: авиационный транспорт, государственное регулирование, безопасность авиации, угрозы, риски, институциональные меры.

Introduction. The 17 sustainable development goals on the 2030 Agenda can be used as benchmarks for the coordinated development of UN member states [1]. The aviation industry is an open system that is affected by a wide range of ecological, technical, natural, human and economic hazards. For its part, it itself is a generator of significant threats to the environment. Therefore, we cannot imagine the aviation industry outside the search for answers to the latest global challenges. The main challenges for aviation are to develop air transportations at the national, regional and global levels, in order to ensure economic, social and environmental priorities [2,3].

Figure 1 shows a Structure of Strategic Management of Aviation Transport in the conditions of sustainable development of national economy.

The article is a logical continuation of a number of publications devoted to the introduction of a systematic approach to determining the level of sustainable development and development of advanced risk management system for air transport safety management of Ukrainian scientists $D$. Bugayko [4 - 6], YM Kharazishvili [4 - 7], A. Antonova [6], M. Hryhorak [5], Poland (Z.
Zamiar [5 - 6]) and other countries. Statistical data for aviation transport risk assessment are taken from the following statistical sources of the State Statistics Service [8], Ministry of Infrastructure [9], the Civil Aviation Authorities [10] and National Bureau for the Investigation of Aviation Accidents and Incidents with Civil Aircraft of Ukraine [11-17].

The purpose of the article is to develop at the level of state regulation of institutional measures to neutralize current hazards in the field of air transport safety, which is actually a set of proactive risk reduction measures to support further sustainable development of the national economy.

Presentation of the main results. The air transport is an open system that is affected by a wide range of technical, natural, human and economic hazards. Each hazard creates a number of risks. According to the concept of national aviation risk management developed by the authors, risk can be assessed as a mutual combination of hazard, vulnerability and consequences. The application of this concept in relation to the air transport of Ukraine allowed identifying the main hazard, vulnerabilities, consequences and risks. 
SDG - UN 2030 Agenda for Sustainable Development
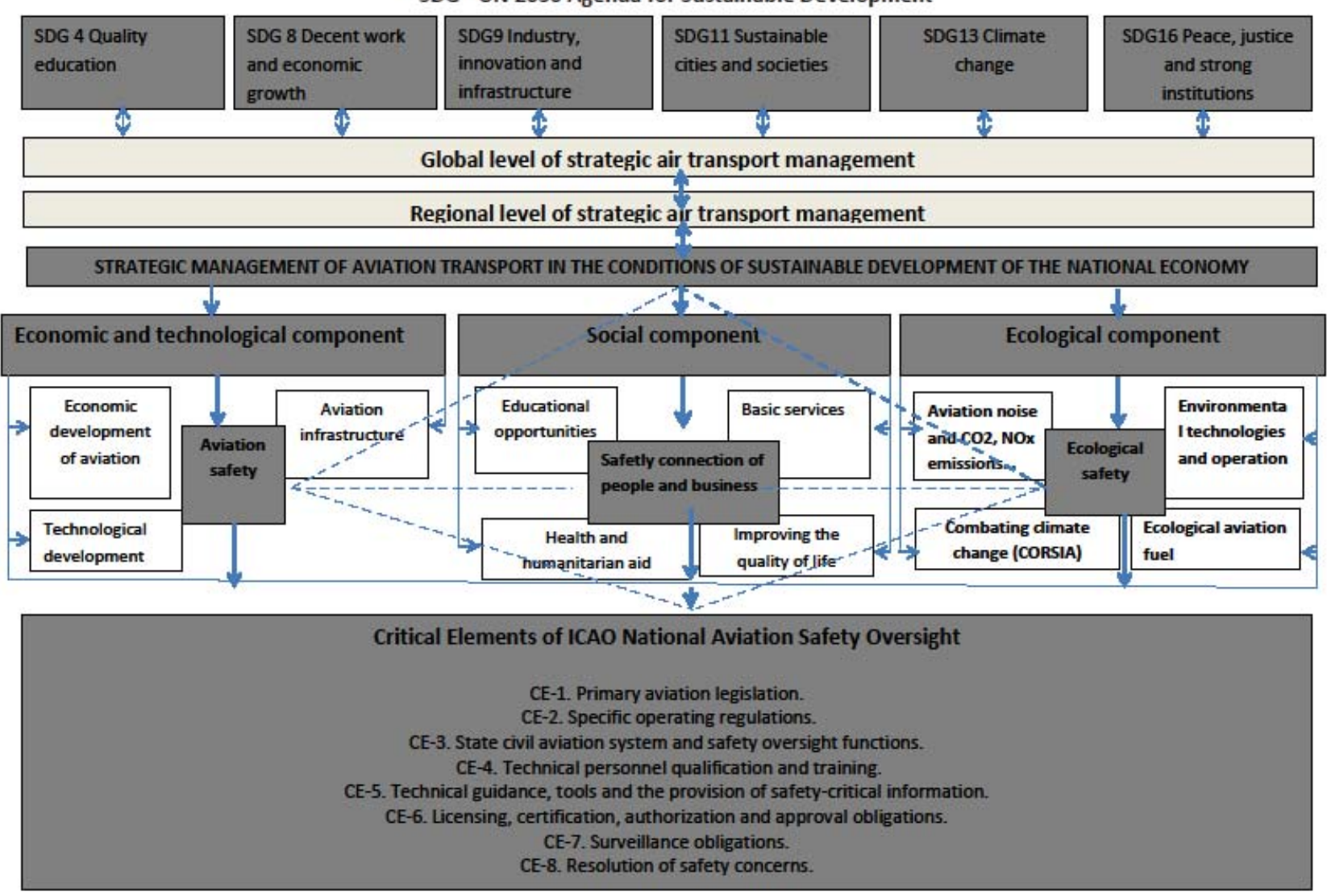

Figure 1. Structure of Strategic Management of Aviation Transport in the conditions of sustainable development of national economy

Source: Bugayko D.O., Kharazishvili Yu.M. Theoretical bases of aviation branch strategic safety management in the context of maintenance of sustainable development of national economy. Bulletin of Economic Science of Ukraine. 2020. № 1 (38). Pp. 166-175. Institute of Industrial Economics of the National Academy of Sciences of Ukraine, Academy of Economic Sciences of Ukraine. doi: https://doi.org/10.37405/1729-7206.2020.1(38).166-175 10 [3].

The next step in the implementation of the concept is to develop institutional measures to neutralize hazards in the field of aviation safety, which is actually a set of risk reduction measures for further sustainable development of the national economy. Summary information on hazards, vulnerabilities, consequences, risks and institutional measures for strategic management of air safety is given in table 1.

In accordance with the provisions of Annex 19 "Safety Management" to the ICAO Convention on International Civil Aviation (Chicago Convention 1944), at the national level, strategic aviation safety management is implemented within the State Aviation Safety
Program (SSP) [18]. As of the 2021 in Ukraine, this area is regulated by the Civil Aviation Safety Program of Ukraine, which was approved at the meeting of the Aviation Safety Council of the State Aviation Service of Ukraine on March 27, 2018. The program has a structure in accordance with ICAO requirements. However, its main drawback is the level of its signatories. Unlike most countries in the world, where this program has been approved at the level of the legislature (parliament), in some cases the Cabinet of Ministers or the National Security and Defense Council, in Ukraine it is published at the regulatory level. 
Thus, the basis of this program - resource security of air transport of the state. Only when the program receives real state support, it is possible to claim its effectiveness. Currently, the issue of development and approval of the State Program on Air Transport Safety on the basis of standards and recommended practices of the International Civil Aviation Organization is included in the Program of Activities of the Cabinet of Ministers of Ukraine. According to the announced indicators of the Civil Aviation Safety Program of Ukraine of the State Aviation Service, by 2022 the country should ensure a $100 \%$ level of implementation of the State Aviation Safety Program, which as of the first quarter of the year does not actually exist. This is a significant risk of strategic aviation safety management, which may adversely affect the results of the next ICAO audit.

The program has to contain the following structural components:

1. State policy, goals and resources in the field of aviation safety. It consists of the following elements: basic aviation legislation; specific rules of operation; state system and functions; qualified technical staff; technical instructional material, tools and provision of information important from the point of view of flight safety.

2. Management of risk factors for aviation safety at the state level. States must identify potential safety factors inherent in the aviation system. To do this, the state should supplement its traditional methods of analyzing the causes of an aviation accident or incident with proactive processes. Proactive processes make it possible to identify predictors of aviation events and the factors that contribute to them, to take appropriate measures, as well as to strategically manage resources in the field of flight safety in order to maximize the level of flight safety.

3. Ensuring of aviation safety at the state level. The state's activities to ensure flight safety are designed to ensure that its functions lead to the achievement of goals and target levels in the field of aviation safety.
State aviation safety management actions under the State Aviation Safety Program ensure that its aviation safety processes work effectively and that the state is on track to achieve its safety objectives through the collective efforts of aviation actors and state.

4. Promotion of aviation safety issues at the state level. The need to implement internal and external measures to promote safety at the state level is set out in Annex 19 as one of the components of the state's responsibilities in the field of safety management. Mechanisms should be established to provide up-to-date safety information to national aviation community in order to promote the formation of culture and, consequently, the effectiveness and efficiency of the State Aviation Safety Program.

The main structural part of the State Aviation Safety Program should be the critical elements (CE) of the national aviation safety control ICAO, namely:

CE 1. Basic aviation legislation;

CE 2. Specific regulations on operation;

CE 3. State system of civil aviation and state functions of control over aviation safety,

CE 4. Qualification and training of personnel;

CE 5. Technical instructional material, tools and information in terms of aviation safety;

CE 6. Obligations to issue certificates, certification, authorization and approval;

CE 7. Obligations to supervise;

CE 8. Solving aviation safety problems.

This is the basis for the state to maintain a national acceptable level of aviation safety.

State program to counteract the negative impact of COVID-19 on air transport in order to support the sustainable development of the national economy. Successfully addressing the challenges posed by the COVID-19 pandemic requires assessing and managing risk factors that go beyond safety risk management. National civil aviation authorities should take into account the possible consequences of their decisions for the risks faced by other public authorities. 


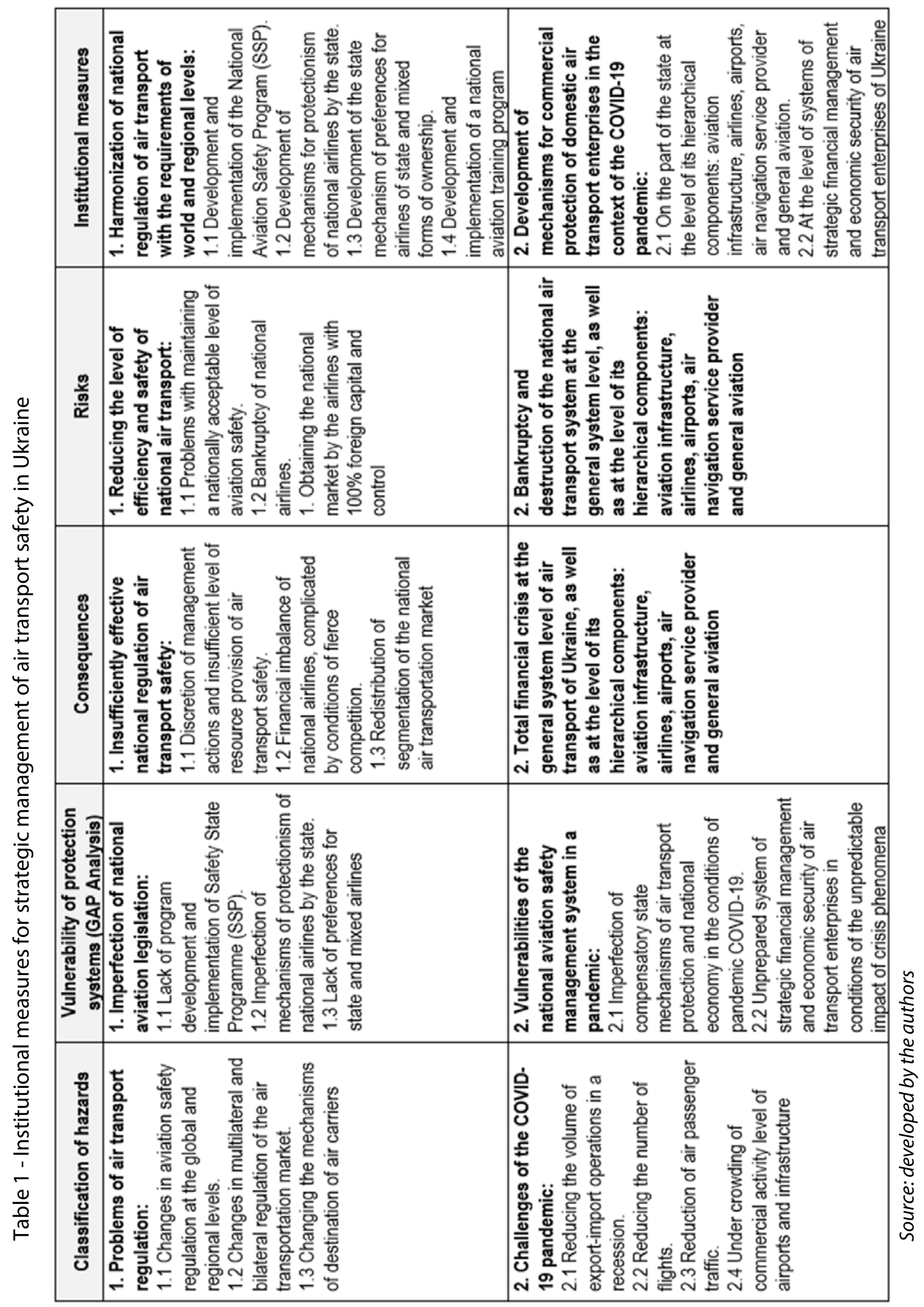


It is proposed to pay special attention to the following priority measures to counter the COVID-19 pandemic:

- risk assessment and prioritization based on data collection and analysis;

- application of aviation safety management principles in decision-making based on risk analysis;

- process management and monitoring of decisions of civil aviation agencies, taking into account the flexibility that must be shown within the aviation system to continue safe operations.

Methods of cooperation, interaction and communication (cooperate, collaborate and communicate) are the most important elements of action of many countries in a global crisis. Civil aviation authorities should recognize that these existing functions also on an ongoing basis contribute to the effective implementation of the State Aviation Safety Program and play an important role in managing aviation safety risks, including the risks of COVID-19 impacts on the aviation system. The program recommends defining mechanisms for state protectionism and granting preferences to airlines of state and mixed ownership of Ukraine and supporting the airport network during a pandemic.

Thus, air transport is one of the sectors of the economy that has been most affected by the pandemic. Crisis phenomena of air transport, in turn, can negatively affect the state of sustainable development of the national economy of Ukraine. Counteraction to them should be based on the implementation of measures to anticipate the integrated risks of air transport.

National aviation training program. One of the most effective tools for the protection of air transport is the training, retraining and advanced training of aviation specialists, which is based on modern competencybased approaches to solving problems of aviation safety.
According to the forecasts of the world's leading civil aviation organizations, every 1520 years there is a double increase in the number of flights. In 10 years, global passenger traffic will reach 14 billion. This necessitates the training of more than 491,000 pilots, 100,000 air traffic controllers, 1 million flight attendants and more than 500,000 aircraft maintenance personnel in the next 20 years. According to experts, in the period up to 2036, the air transport industry will create 15.5 million direct jobs and attract 1.5 trillion dollars GDP for the world economy. At the same time, the existing, and most importantly projected, capacity of aviation training centers is far from the demand for training of aviation specialists.

According to ICAO's Global Safety Plan, the global level of critical aviation safety oversight element 4, which includes the availability of qualified aviation technical personnel, is only $52 \%$. It is the lowest of all 8 critical elements and one of the major GAPs in global aviation.

According to ICAO's strategies, the implementation of the aviation safety management system is regulated at three hierarchical levels - global, regionalinternational and national.

The global level is based on the standards and recommended practices (SARPS) of the International Civil Aviation Organization (ICAO), published in the annexes to the Convention on International Civil Aviation (Chicago Convention). ICAO's aviation safety management system is based on management commitments and aims to address safety and cost-effectiveness issues.

The regional and international level is based on the activities of regional aviation organizations, such as EUROCONTROL, the European Civil Aviation Conference (ECAC), the European Aviation Safety Agency (EASA) and adapts ICAO standards and recommended practices to regional specifics and requirements.

The national level is based on the activities of national aviation organizations, such as the National Supervisory Authorities 
(NSA), the Civil Aviation Authorities (CAA), the State Aviation Administration (SAA), and the National Aviation and Transport Universities (National Aviation University, Kyiv).

The global, regional, international and national levels are hierarchically interconnected and coherent.

It should be noted that higher education and research institutions play an important role in the developed curricula, technologies and rules. The National Aviation University of the Ministry of Education and Science of Ukraine pays special attention to aviation safety issues and has been developing joint scientific and educational activities in this field for many years. Content of coordination of training and retraining of aviation safety specialists in 2003 The ICAO Institute was established at the National Aviation University. The institute includes the ICAO European Regional Training Center for Aviation Safety, the ICAO European Regional Training Center for the Training of State Inspectors for Air Safety and Airworthiness of Aircraft, as well as national training centers. Since 2003, about 20.5 thousand employees of aviation administrations, airlines, airports, aviation enterprises, aero clubs and aviation educational institutions of Ukraine and 77 countries have been trained and retrained in the training centers of the institute [19].

However, the needs of the aviation sector are not met only by aviation personnel - cyber security, environmental safety, biotechnology (for example, for biofuel production), economics and management, international aviation law also requires highly qualified specialists. Multidisciplinary is the hallmark of international aviation education in the period of globalization. This creates a need to train 50-60 million professionals in related economic sectors (induced and catalytic business), which are related to the activities of the aviation industry. And almost the entire list can be found in the names of specialties in which students of the National Aviation University study today. If we consider further - the prospects for the development of the industry globally indicate a significant increase in demand for both the latest technology and aviation personnel, as well as in the catalytic age of related sectors, special tourism and logistics.

It follows that higher education and research institutions play an important role in the developed curricula, technologies and rules. Specialists of the National Aviation University and the Institute of Industrial Economics of the National Academy of Sciences of Ukraine have paid special attention to aviation safety and have been developing scientific and educational activities in this field for many years. Their cooperation is of great importance in improving the safety of air transport.

Institutional measures of strategic security management at the level of interaction between the state and airlines of Ukraine. The level of competitiveness of Ukrainian air transport enterprises is significantly influenced by current trends in the development of world civil aviation. Over the last decade, there have been significant changes in the field of civil aviation that need to be taken into account. The most important of them are: changes in air transport regulation, liberalization policy, changes in the structure of the industry, the emergence of new sales channels, the development of alliances between airlines, the emergence of new business models of airlines, privatization of airlines, fierce competition between carriers, especially international levels, problems of updating the fleet of aircraft, rising fuel prices. Today, the issue of increasing the competitiveness of airlines in the current trends of civil aviation, the COVID-19 pandemic and fierce market competition remains unresolved. An urgent problem is the search for new ways to increase the commercial operation of international airlines.

One of the most important trends in the field of air transport is the liberalization of regulation of international wind routes. Today, more and more states are becoming parties to agreements on widespread market access. At the national level, states have begun the process of reviewing their air 
transport policy in the light of the global trend towards greater liberalization. Some of these concepts aim to liberalize air services in whole or in part unilaterally without requirements instead of comparable rights from partners in bilateral agreements. Others focus on liberalizing domestic air transport markets and also allowing more carriers to operate international routes.

At the bilateral level, more than $70 \%$ of bilateral air services agreements recently concluded or revised contained forms of arrangements that liberalized some aspects of aviation cooperation, such as unrestricted commercial rights (rights of the third, fourth and in some cases fifth freedoms), the appointment of several carriers with or without restrictions on routes, the free introduction of capacity, liberal modes of tariff setting and freer criteria for the ownership and control of air carriers.

An important change is the significant increase in the number of open skies agreements, which provide full market access without restrictions on destinations, routes, capacity, frequencies, code sharing and tariffs. These agreements included not only developed countries, but also a growing number of developing countries (which participate in more than $60 \%$ of agreements).

Other more general regulatory measures also apply to air transport. Such measures include the adoption of competition laws, the introduction of various taxes, the expansion of the responsibility of airlines for compliance with the requirements for entry into the country (especially for passengers who do not have the right to do so), the introduction of more stringent health requirements. entry into the country, as well as national drug control programs.

Another trend in global civil aviation today is changes in the structure of the air transport industry, which traditionally stem from the need to meet the growing demand for air transport services in markets with increasing competition and in a more globalized economic environment.
Megacarriers in the United States use a new operational approach: the use of large "complexes" of connecting flights to maximize the number of pairs of cities that can be served by each flight. This approach arose from the perceived need to use multiple hub airports and achieve "critical mass" (sufficient to save size and frequency to influence market conditions to maximize revenue and provide seats efficiently).

The unit of control of specific revenues has allowed long-standing airlines with high costs in some cases to selectively compete with low-cost airlines (Low Cost Airlines, Discounters Airlines), which often rely on low fares to enter the market.

An important change in the sale and sale of airline services, which combines the use of computers and personal communication systems, is direct sales to consumers, including through the Internet. Although much of the airline ticket sales are still made through traditional travel agencies, the share of direct online sales over the Internet is growing rapidly, especially in countries with high Internet and credit card spreads. This course of events created not only new opportunities, but also new problems for airlines and computer reservation service providers. Many airlines have begun to increase online sales as a way to reduce sales costs. Some have teamed up to create relevant web pages to maximize the benefits of e-commerce. Four global computer reservation systems (Amadeus, Galileo, Saber and World Span) have also taken steps to adapt to the new commercial environment and have begun to explore the Internet market through various strategic decisions, becoming global distribution systems that offer comprehensive information, booking services and methods. e-commerce for travel and tourism (air travel, car rental, development of other modes of transport, hotel, places of rest).

Airlines are increasingly using innovative technology-based measures to increase productivity and optimize revenue, including the use of automated systems to manage 
profit rates, marketing, sales and communication.

First, the creation of advanced computerbased rate management systems allows airlines to operate on each flight with high (normal) and low (special) fares to maximize revenue and provide seats efficiently.

The privatization of state-owned airlines has been one of the outstanding transformations in the field of international air transport, where, with the exception of a few states, airlines have until recently been stateowned. The motives for privatization were different - from purely economic considerations or to increase operational efficiency and competitiveness to the intention to reduce the financial burden of the state to finance investments in new equipment.

The latest trend is due to the large number of reduced direct routes and dosing landings, making flights more comfortable for passengers. As the speed of aircraft increased and the number of stops decreased, the total flight time of passengers decreased, especially on routes consisting of many stages of flight. In response to increasing demand for air transportation, factors such as economic development, airlines are spending at no cost to increase the frequency of flights and introduce non-stop cities between a large numbers of pairs.

As for air cargo, these are highly organized airlines/parcel delivery companies, which have developed significantly over the last decade, continue to expand this specialized type of service. These companies use large jet fleets combined through ground delivery systems to ensure the delivery of strategic high-end airport hubs the next day on continental flights and the next day on intercontinental flights. This concept was also chosen near postal administrations.

Today in the global aviation industry there are negative trends that affect the decline in demand for air transportation, namely: financial instability in the world, inflation, rising prices and unemployment. In addition, the problem of fleet modernization has recently become more acute. Many airlines need a fleet because their upgrades are moral and do not meet aviation safety standards. Solving the problems facing the aviation industry at the present stage will be a step forward in the development of global air transport.

The competitiveness of Ukrainian air transport enterprises can increase both at the state level and at the airline level (Fig. 2).

In order to assess the effectiveness of the use of these methods in the activities of the airline, it is necessary to consider them in more detail.

1. At the state level, increasing the competitiveness of airlines can be done using the following methods:

1.1 Introduction of a protectionist policy that will limit the activities of foreign airlines in the air transportation market of Ukraine.

1.2 Creating conditions for the formation of flagship and regional (feeder) air carriers.

1.3 Implementation of regulatory policy to build a harmonized infrastructure in the field of civil aviation of Ukraine (creation of an effective network of aviation enterprises). The use of internal measures by the air transport companies of Ukraine is more effective due to their clear focus and direct consideration of the interests of the airline. Modern airlines aim to distinguish their own service among the many offers of competitors and use a number of methods. Their introduction will increase the efficiency of both domestic and international markets; provide its own transportation service with new properties that will help increase competitiveness.

2. At the level of air transport enterprises of Ukraine the following methods of increasing competitiveness may be introduced:

2.1 Introduction of new technologies. Technological methods of increasing the attractiveness of own transportation services are widespread in the transportation market. 


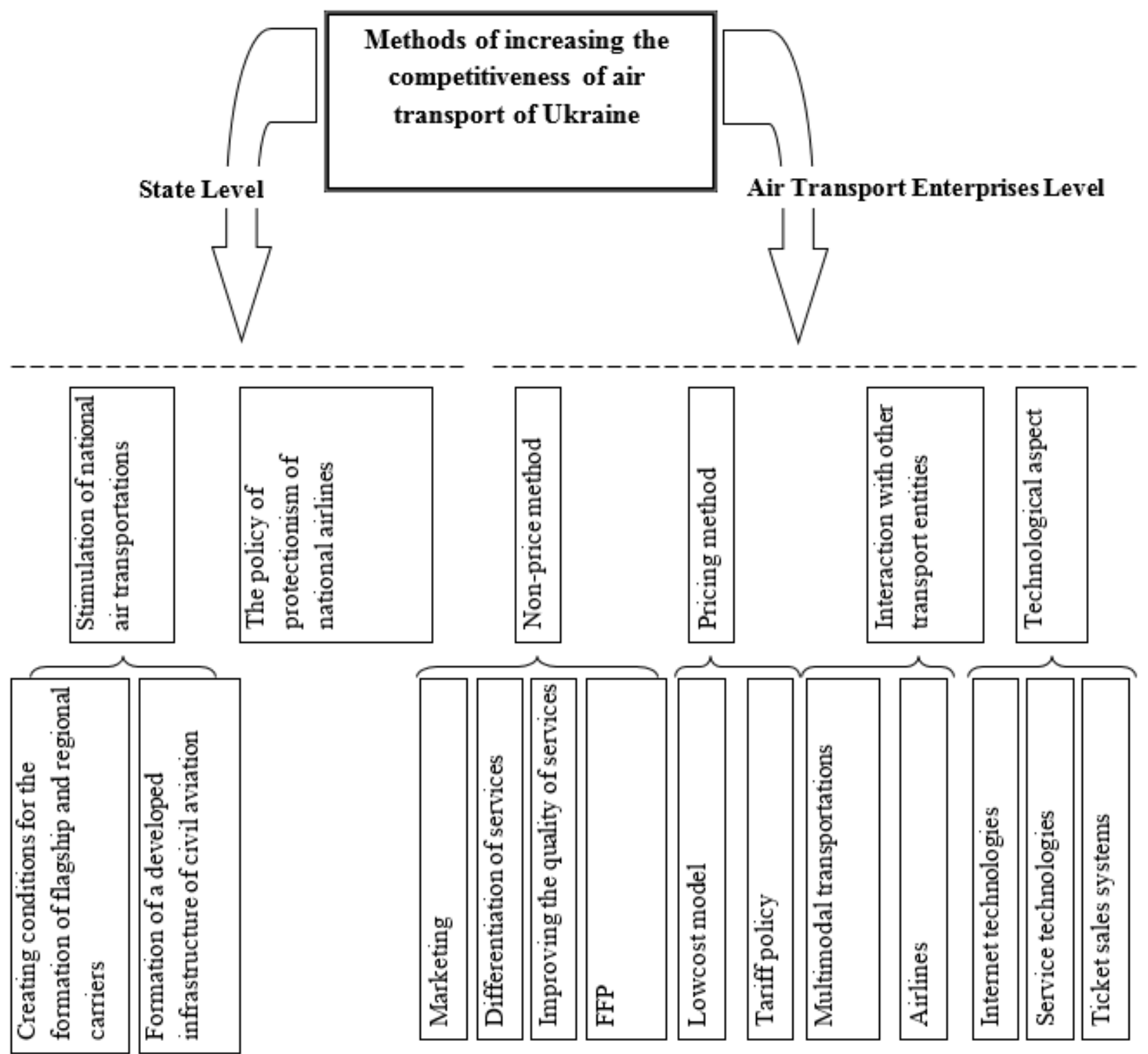

Figure 2. Methodology of increasing competitiveness air transport of Ukraine Source: compiled according to data [63, p. 195, 198].

Modern technological solutions in the field of civil aviation include:

- use of the Internet at all stages of the service life cycle - from the sale of transportation to online registration;

- service "registration in the city";

- landing in the aircraft by means of telescopic gates.

2.2 Non-price method of increasing competitiveness - these methods are widespread among airlines around the world (British Airways, Lufthansa, Delta Airlines, etc.). There are the following measures:
- programs for passengers who fly frequently;

- differentiation of services;

- provision of additional services;

- improving the quality of services;

- other marketing activities (advertising, company image, a certain positioning of the service in the market).

These measures are becoming increasingly important in a saturated air transportation market. Since all air transport companies provide the same service in the general concept - air transportation, the use of such methods allows providing the service 
with certain special characteristics, properties that will distinguish it from the service of competitors. In addition, most non-price methods are aimed at attracting regular customers (for example, programs for passengers who fly frequently). The formation of this category of passengers is one of the airline's top priorities.

However, the expansion of the non-price method is limited, because the study of various methods of increasing competitiveness found that in times of economic downturn, not all methods of nonprice policy are appropriate for use. For example, the provision of additional free services to passengers increases the cost of the carrier and has a low incentive function due to the general decline in financial activity.

2.3 The price method of increasing competitiveness is one of the most influential factors in the demand for air transportation, which includes two instruments:

- tariff policy;

- use of the principles of the mechanism of activity of low-cost airlines. Since the demand for air transportation services is characterized by high elasticity, ie even with slight fluctuations in the price of transportation, the magnitude of demand varies significantly, it is important to study the tariff policy of the airline.

2.4 Cooperation, interaction with other subjects of the transportation market:

- joining global aviation alliances;

- creation of alliances between regional airlines;

- creation of alliances between air carriers of Ukraine;

- creation of alliances of airlines with carriers of automobile, railway and other types of transport.

Conclusions. The aviation transport is a part of the transport complex of Ukraine, which is an important component in the structure of the national economy and a link between all components of economic security to ensure the basic conditions of life and development of the state and society. The assessment of economic, technological, safety, social and ecological hazards is an integral part of all the logical blocks of the structural and functional scheme of strategic management of aviation safety in terms of sustainable development of the national economy.

Thus, the fruitful international cooperation of leading aviation and transport universities, such as the National Aviation University, as well as cooperation with leading national centers of economics, such as the Institute of Industrial Economics of the National Academy of Science of Ukraine, formed recommendations for three levels of civil aviation regulation.

For the global level, it is the creation of international standards and recommendations in the field of aviation and the exchange of leading experience.

For the regional level - recommendations for adapting standards to regional features and requirements.

For the national level - the direct implementation of global and regional standards in the process of training a new generation of aviation professionals, as well as the development of new innovative areas of training of related economic sectors.

Research and innovation activities of universities are aimed at the introduction of innovative technologies in the field of air transport, and the training of highly qualified specialists is the basis for its further development. Under such conditions, the development of the State Aviation Training Program under the auspices of the Ministry of Education and Science of Ukraine, the National Academy of Sciences of Ukraine, the Ministry of Infrastructure of Ukraine, the State Aviation Service of Ukraine, the State Aviation Department of the Ministry of Defense of Ukraine is relevant. transport for the sustainable development of the national economy. 


\section{References}

1. Resolution adopted by the General Assembly (UN) on 25 September 2015 A / RES / 70/1. Transforming our world: the 2030 Agenda for Sustainable Development.

2. Aviation Benefits Report 2019, ICAO (Report based on material from ACl, CANSO, IATA, ICAO, ICCAIA, ATAG).

3. Convention on International Civil Aviation (Doc 7300), signed at Chicago on December 7, 1944.

4. D. Bugayko, Yu. Kharazishvili. Theoretical principles of strategic aviation safety management in the context of ensuring sustainable development of the national economy. Bulletin of Economic Science of Ukraine. 2020. № 1 (38). P. 166-175. Institute of Industrial Economics of the National Academy of Sciences of Ukraine, Academy of Economic Sciences of Ukraine.

5. D.Bugayko, Yu. Kharazishvili, M.Hryhorak, Z.Zamiar. Economic Risk Management of Civil Aviation in the Context of Ensuring Sustainable Development of the National Economy. Logistics and Transport- Wroclaw: International School of Logistics and Transport in Wroclaw. - 2020. - №12(45-46). - P.71- 82.

6. D. Bugayko, Yu. Kharazishvili, A.Antonova, Z.Zamiar. Identification of Air Transport Ecological Component Level in the Context of Ensuring Sustainable Development of the National Economy. Intellectualization of Logistics and Supply Chain Management. The electronic scientifically and practical journal № 3 (2020) October 2020 ISSN 2708-3195 DOI: https://doi.org/10.46783/smart-scm/2020-3. P.38 - 53. https://smart-scm.org/wpcontent/uploads/3_20_titul_j_full.pdf.

7. Kharazishvili Yu.M. Systemic security of sustainable development: assessment tools, reserves and strategic scenarios of implementation: monograph / NAS of Ukraine, Institute of Industrial Economics. - Ki-ate, 2019. - 304 p.

8. Statistical collection "Transport and Communications of Ukraine" 2018. http://www.ukrstat.gov.ua/druk/publicat/kat_u/publ8_u.htm

9. Report of the Head of the State Aviation Service of Ukraine for 2019 - [Electronics resource]: $\quad$ https://www.kmu.gov.ua/storage/app/sites/1/17-civik-2018/zvit_2019/zvit-2019avia.pdf

10. The results of the aviation industry of Ukraine for 2016 - [Electronics resource]: https://avia.gov.ua/wp-content/uploads/2017/04/Pidsumky-roboty-2016.pdf

11. "Analysis of the state of aviation safety based on the results of the investigation of aviation accidence and incidents with civil aircraft of Ukraine and foreign-registered aircraft in 2013". National Bureau for Investigation of Aviation Accidence and Incidents with Civil Aircraft: http://www.nbaai.gov.ua/uploads/pdf/Analysis_2013.pdf

12. "Analysis of the state of aviation safety based on the results of the investigation of aviation accidence and incidents with civil aircraft of Ukraine and foreign-registered aircraft in 2014". National Bureau for Investigation of Aviation Accidence and Incidents with Civil Aircraft: http://www.nbaai.gov.ua/uploads/pdf/Analysis_2014.pdf 
13. "Analysis of the state of aviation safety based on the results of the investigation of aviation accidence and incidents with civil aircraft of Ukraine and foreign-registered aircraft in 2015". National Bureau for Investigation of Aviation Accidence and Incidents with Civil Aircraft: http://www.nbaai.gov.ua/uploads/pdf/Analysis_2015.pdf

14. "Analysis of the state of aviation safety based on the results of the investigation of aviation accidence and incidents with civil aircraft of Ukraine and foreign-registered aircraft in 2016". National Bureau for Investigation of Aviation Accidence and Incidents with Civil Aircraft: http://www.nbaai.gov.ua/uploads/pdf/Analysis_2016.pdf

15. "Analysis of the state of aviation safety based on the results of the investigation of aviation accidence and incidents with civil aircraft of Ukraine and foreign-registered aircraft in 2017". National Bureau for Investigation of Aviation Accidence and Incidents with Civil Aircraft: http://www.nbaai.gov.ua/uploads/pdf/Analysis_2017.pdf

16. "Analysis of the state of aviation safety based on the results of the investigation of aviation accidence and incidents with civil aircraft of Ukraine and foreign-registered aircraft in 2018". National Bureau for Investigation of Aviation Accidence and Incidents with Civil Aircraft: http://www.nbaai.gov.ua/uploads/pdf/Analysis2018.pdf

17. "Analysis of the state of aviation safety based on the results of the investigation of aviation accidence and incidents with civil aircraft of Ukraine and foreign-registered aircraft in 2019". National Bureau for Investigation of Aviation Accidence and Incidents with Civil Aircraft: http://www.nbaai.gov.ua/uploads/pdf/Analysis_2019.pdf

18. Annex 19 to the Convention on International Civil Aviation. Safety management. 2nd ed. International Civil Aviation Organization. 2016. July. URL: http://caa.gov.by/uploads/files/ICAOPr19-ru-izd-2-2016.pdf.

19. D.Bugayko, V.Isaienko, V.Kharchenko, M.Paweska. Challenges of International Science and Education in the Field of Aviation Transport Safety. Logistics and Transport. [Wroclaw]. 2018. № 2 (38). P. 23-32. 